\title{
Incidence of Stem Rot Disease in North-Eastern Region of Karnataka, India
}

\author{
D. Pramesh ${ }^{1,2^{*}}$, Saddamhusen Alase ${ }^{1,2}$, M. Kirana Kumara ${ }^{1,2}$ and K.M. Muniraju ${ }^{1,2}$ \\ ${ }^{1}$ All India Coordinated Rice Improvement Programme, Agricultural Research Station, \\ Gangavathi-583 227, Karnataka, India \\ ${ }^{2}$ Department of Plant Pathology, University of Agricultural Sciences, Raichur-584104, \\ Karnataka, India \\ *Corresponding author
}

A B S T R A C T

\begin{tabular}{l} 
K e y w or d s \\
Stem rot, Survey, \\
Karnataka, \\
Incidence, \\
Ecosystem. \\
\hline Article Info \\
$\begin{array}{l}\text { Accepted: } \\
\text { 26 September } 2017 \\
\text { Available Online: } \\
10 \text { October } 2017\end{array}$
\end{tabular}

Keywords

Stem rot, Survey,

Karnataka,

Incidence,

Ecosystem

Article Info

26 September 2017

10 October 2017
A roving survey was carried out during Kharif 2014 and 2015 in different rice growing taluks of North-eastern Karnataka to ascertain the stem rot disease of rice. Disease was recorded in all the surveyed location in both 2014 and 2015. In Kharif 2014, the mean disease incidence of taluks was ranged from 12.35 to 29.55 percent whereas; it was 4.78 to14.33 during Kharif 2015. The highest disease incidence of 29.55 and 14.33 percent was observed in Gangavathi taluk during Kharif 2014 and 2015 respectively. All the cultivated varieties were infected with the disease in both transplanted and direct seeded cropping system, indicating its wider distribution in the North-eastern paddy ecosystems of Karnataka. The information generated could be useful for prioritising the research to reduce the impact of stem rot disease and also to check its further development to cause disease epidemics.

\section{Introduction}

Among the different emerging biotic stresses for rice production, stem rot of rice caused by Sclerotium oryzae is becoming a serious problem of rice cultivation in the Indian subcontinent (Singh and Devi, 1999; Singh et al., 2002; Pramesh and Guruprasad, 2014; Gopika et al., 2016). The causal agent was first described from Italy in the sclerotial form and was named S. oryzae Catt. (Cattaneo, 1876). The sclerotia produced by the fungus serve as primary inoculum by floating on the water and infecting rice stems at the waterline (Keim and Webster, 1973). Sclerotia form abundantly in infected tissues as the rice plant nears maturity and continue to form in crop debris (Keim and Webster, 1973). Pathogen overwinters as sclerotia in the soil and plant debris and serves as the primary source of inoculum for subsequent crop. During irrigation the sclerotia float to the surface and infect the plant at water line and further manifested as blackened lesion at the leaf sheath at soil line and progress inward. Under severe infection, culm also infected and shows rotting and finally lodging occurs (Keim and Webster, 1973; Singh et al., 2002). In India, Singh and Devi (1999) reported the occurrence of stem rot disease of rice in 
Manipur in almost all the varieties cultivated. In Karnataka, this disease occurred in epidemic form during 2012-13 and yield loss up to $30 \%$ was reported on paddy cultivar BPT5204 in North eastern part of Karnataka (Pramesh and Guruprasad, 2014). This disease was also reported to be the major constraint for paddy cultivation in Andhra Pradesh state in recent years (Gopika et al., 2016).

In Karnataka, North-eastern region is an important paddy growing region which occupies more than 60,000 ha of paddy and stem rot disease is an emerging threat for rice cultivation in this region (Pramesh and Guruprasad, 2014). The disease has been reported to cause 5-80 per cent losses in grain yield in different parts of the world including in India (AI-Heeti and EI-Bahadli, 1982; Li et al., 1984; Ou, 1985; Cother and Nicol, 1999; Kumar et al., 2003). Although, the disease was reported from Karnataka during 2012-13 (Pramesh and Guruprasad, 2014), the information on the disease status is limited. Therefore, present investigation was undertaken to ascertain the disease status in different rice growing taluks of North-eastern Karnataka.

\section{Materials and Methods}

\section{Survey to assess disease incidence}

A random roving survey was conducted during Kharif 2014 and 2015 for the incidence of stem rot of rice in different rice growing taluks of North-eastern Karnataka (Tables 1 and 2). In each taluk, two to twelve villages were surveyed and in each village three farmer's fields were selected randomly from both sides of the path. In each field, three random plots of 1 sq.m was selected and observations on number of infected hills $/ \mathrm{m}^{2}$ was recorded. Observation was also recorded on different symptoms, cultivar profile and cultivation type.
Per cent disese incidence $=\frac{\text { Number of hills infected } / \mathrm{m}^{2}}{\text { Total number of hills } / \mathrm{m}^{2}} \times 100$

\section{Isolation of pathogen and pathogenicity}

During survey, plants showing the characteristics symptoms of the stem rot disease were collected for identifying the pathogen. From the infected plant sample, pathogen was isolated using standard procedure. The collected stem rot specimens were surface sterilized with $1 \%$ sodium hypochloride solution for 2-3 minutes. The sclerotia present in the culm were aseptically transferred to potato dextrose agar plates. The inoculated petridishes were then incubated at $25 \pm 1^{0} \mathrm{C}$ for 3 days. Petridishes with white mat of the fungi was incubated at $25 \pm 1^{0} \mathrm{C}$ for 20 days for sclerotia formation and pure culture of the pathogen was obtained by sub culturing the sclerotia produced.

Pure culture of the pathogen was inoculated to rice grain husk + sand medium $(2: 1)$ in 250 $\mathrm{ml}$ Erlenmeyer flasks at $28 \pm 2^{0} \mathrm{C}$ for 20 days as described previously (Kumar, et al., 2003).

After 20 days, $150 \mathrm{~g}$ of $S$. oryzae inoculated rice grain husk + sand medium was added to earthen pot sown with seeds of susceptible rice cultivar BPT5204 for proving pathogenicity.

\section{Results and Discussion}

Stem rot disease of rice is an emerging threat for rice cultivation in India. It has been reported in late 1990s from North Eastern India (Singh and Devi, 1999) and later from other rice growing states of the country (Singh et al., 2002; Kumar et al., 2003; Pramesh and Guruprasad, 2014; Gopika et al., 2016). This disease has shown its potentiality to reduce the grain yield up to $80 \%$ worldwide (AI-Heeti and EI-Bahadli, 1982; Li et al., 1984; Ou, 1985; Cother and Nicol, 1999). 
Table.1 Assessment of stem rot disease in different paddy growing regions of North-eastern Karnataka during Kharif 2014

\begin{tabular}{|c|c|c|c|c|c|}
\hline S.No. & Taluks & Villages & Type of Planting & Cultivars & $\begin{array}{l}\text { Disease Incidence } \\
\text { (Average) }\end{array}$ \\
\hline 1 & Koppal & Munirabad, Hosahalli, Hitnal, Budagumpa & Transplanting & $\begin{array}{l}\text { BPT5204, Kavery Sona, } \\
\text { GNV-05-01 }\end{array}$ & 12.55 \\
\hline 2 & Gangavathi & $\begin{array}{l}\text { Anegundi, Karatagi, Desai Camp, Marali, } \\
\text { Siddapura, Jangamara Kalgudi, Vaddarahatti, } \\
\text { Basavapatna, Kesarahatti, Hanval }\end{array}$ & Transplanting & $\begin{array}{l}\text { BPT5204, Kavery Sona, } \\
\text { GNV-05-01, Nellur Sona }\end{array}$ & 29.55 \\
\hline 3 & Hosapete & Ramsagara, Kampli, Bukkasagara, Kamalapura & Transplanted & BPT5204, IR64, JGL1598 & 18.57 \\
\hline 4 & Bellary & $\begin{array}{l}\text { Kurgodu, Somsamudra, Roopanagudi, } \\
\text { Toranagallu, Daroji }\end{array}$ & Transplanted & $\begin{array}{l}\text { BPT5204, IR-64, Kavary } \\
\text { Sona }\end{array}$ & 14.32 \\
\hline 5 & Sirguppa & Devlapura, Tekkalakote, Halekote, & Transplanted & BPT5204, Kavary Sona & 18.33 \\
\hline 6 & Sindhanur & $\begin{array}{l}\text { Dadesugur, Sripuram, Mataladinni, Javalagere, } \\
\text { Virupapura }\end{array}$ & Transplanted & $\begin{array}{l}\text { BPT5204, Kavary Sona, } \\
\text { GNV-05-01 }\end{array}$ & 23.55 \\
\hline 7 & Manvi & $\begin{array}{l}\text { Neermanvi, Dasanal, Kappagal, Kotnekal, } \\
\text { Amareshwara Camp, }\end{array}$ & Transplanted and DSR & BPT5204, Kavary Sona & 24.32 \\
\hline 8 & Raichur & $\begin{array}{l}\text { Kalluru, Kasabe Camp, Kalmala, Devasuguru, } \\
\text { Gabburu, Sirwara, Kavital }\end{array}$ & DSR, Transplanted & BPT5204, Kavary Sona & 20.78 \\
\hline 9 & Lingsuguru & Mudgal, Karadkal, Honnahalli, Hatti, Gurgunta & Transplanted & BPT5204, Kavary Sona, & 12.35 \\
\hline 10 & Surpura & $\begin{array}{l}\text { Kavadimatti, Tintinni, Malnur, Hunasagi, } \\
\text { Kembhavi, Devapura Cross }\end{array}$ & Transplanted & BPT5204, Kavary Sona & 21.33 \\
\hline 11 & Shapura & Hatti guduru, Bhimarayanagudi, & Transplanted & BPT5204, Kavary Sona & 18.88 \\
\hline
\end{tabular}


Table.2 Assessment of stem rot disease in different paddy growing regions of North-eastern Karnataka during Kharif 2015

\begin{tabular}{|c|c|c|c|c|c|}
\hline S.No. & Taluks & Villages & Type of Planting & Cultivars & $\begin{array}{c}\text { Disease Incidence } \\
\text { (Average) }\end{array}$ \\
\hline 1 & Koppal & $\begin{array}{l}\text { Agalakera, Basapura, Munirabad, Hosahalli, Hitnal, } \\
\text { Budagumpa, Ginigera }\end{array}$ & Transplanting & $\begin{array}{l}\text { BPT5204, Kavery Sona, } \\
\text { GNV-05-01 }\end{array}$ & 11.32 \\
\hline 2 & Gangavathi & $\begin{array}{l}\text { Sannapura, Janthkal, Anegundi, Karatagi, Desai Camp, } \\
\text { Marali, Siddapura, Jangamara Kalgudi, Vaddarahatti, } \\
\text { Basavapatna, Kesarahatti, Hanval }\end{array}$ & Transplanting & $\begin{array}{l}\text { BPT5204, Kavery Sona, } \\
\text { GNV-05-01, Nellur Sona }\end{array}$ & 14.33 \\
\hline 3 & Hosapete & $\begin{array}{l}\text { Kampli, Ramsagara,, Bukkasagara, Kamalapura, } \\
\text { Hampi }\end{array}$ & Transplanted & $\begin{array}{l}\text { BPT5204, IR64, } \\
\text { JGL1598 }\end{array}$ & 10.22 \\
\hline 4 & Bellary & $\begin{array}{l}\text { Kurgodu, Somsamudra, Hagari, Roopanagudi, } \\
\text { Toranagallu, Daroji }\end{array}$ & Transplanted & $\begin{array}{l}\text { BPT5204, IR-64, Kavary } \\
\text { Sona }\end{array}$ & 9.33 \\
\hline 5 & Sirguppa & Devlapura, Tekkalakote, Halekote & Transplanted & BPT5204, Kavary Sona & 3.71 \\
\hline 6 & Sindhanur & $\begin{array}{l}\text { Dadesugur, Sripuram, Mataladinni, Javalagere, } \\
\text { Virupapura }\end{array}$ & Transplanted & $\begin{array}{l}\text { BPT5204, Kavary Sona, } \\
\text { GNV-05-01 }\end{array}$ & 8.42 \\
\hline 7 & Manvi & Neermanvi, Kappagal, Kotnekal, Amareshwara Camp & Transplanted and DSR & BPT5204, Kavary Sona & 11.52 \\
\hline 8 & Raichur & $\begin{array}{l}\text { Kalluru, Kasabe Camp, Kalmala, Devasuguru, } \\
\text { Gabburu, Sirwara, Kavital }\end{array}$ & DSR, Transplanted & BPT5204, Kavary Sona & 4.78 \\
\hline 9 & Lingsuguru & Mudgal, Karadkal, Hatti, Gurgunta & Transplanted & BPT5204, Kavary Sona, & 5.35 \\
\hline 10 & Surpura & $\begin{array}{l}\text { Kavadimatti, Tintinni, Malnur, Hunasagi, Devapura } \\
\text { Cross }\end{array}$ & Transplanted & BPT5204, Kavary Sona & 6.33 \\
\hline 11 & Shapura & Hatti guduru, Bhimarayanagudi & Transplanted & BPT5204, Kavary Sona & 8.80 \\
\hline
\end{tabular}


Fig.1 Symptoms of stem rot disease observed during survey

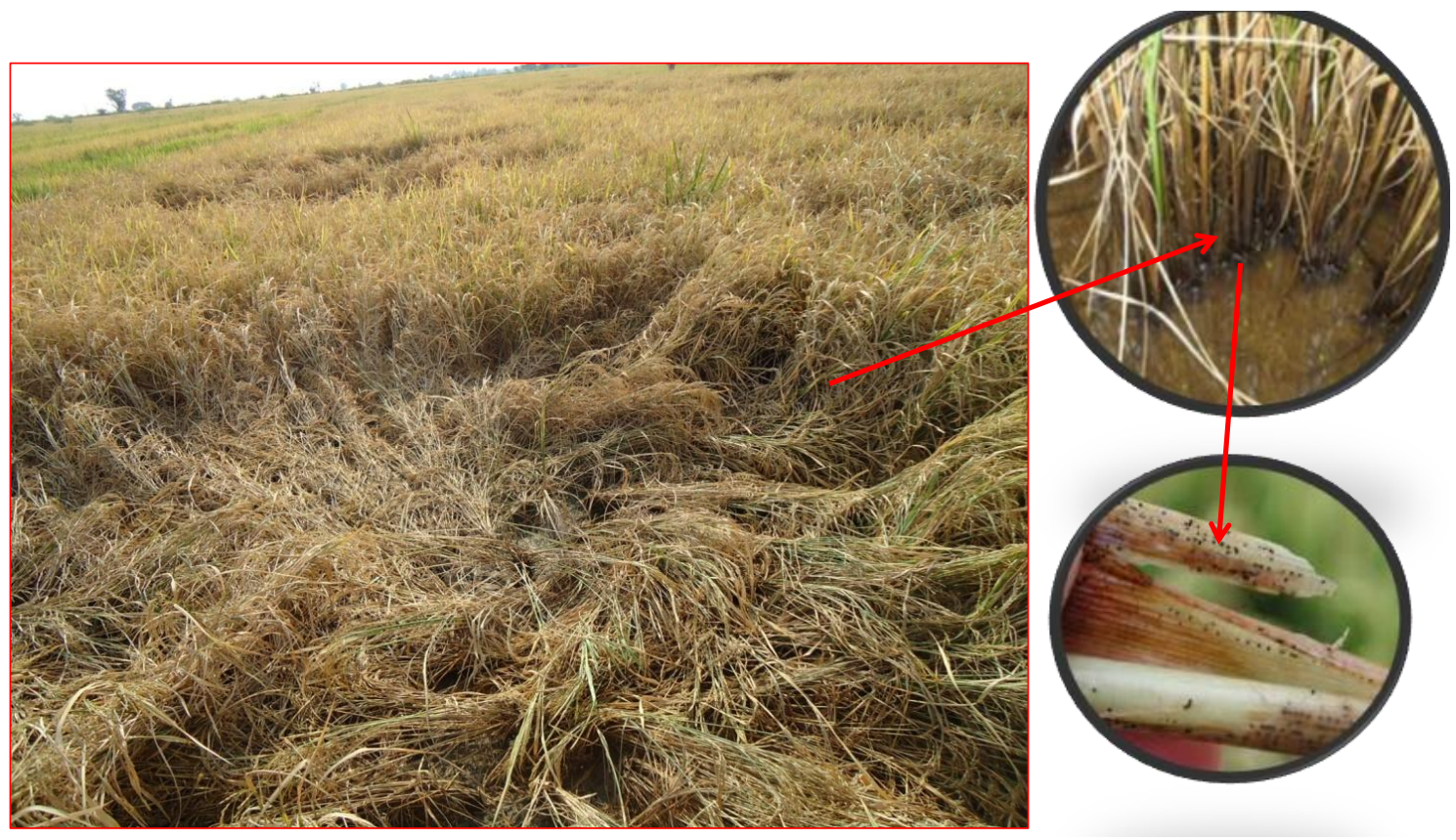

Fig.2 Pathogenicity of Sclerotium oryzae on rice
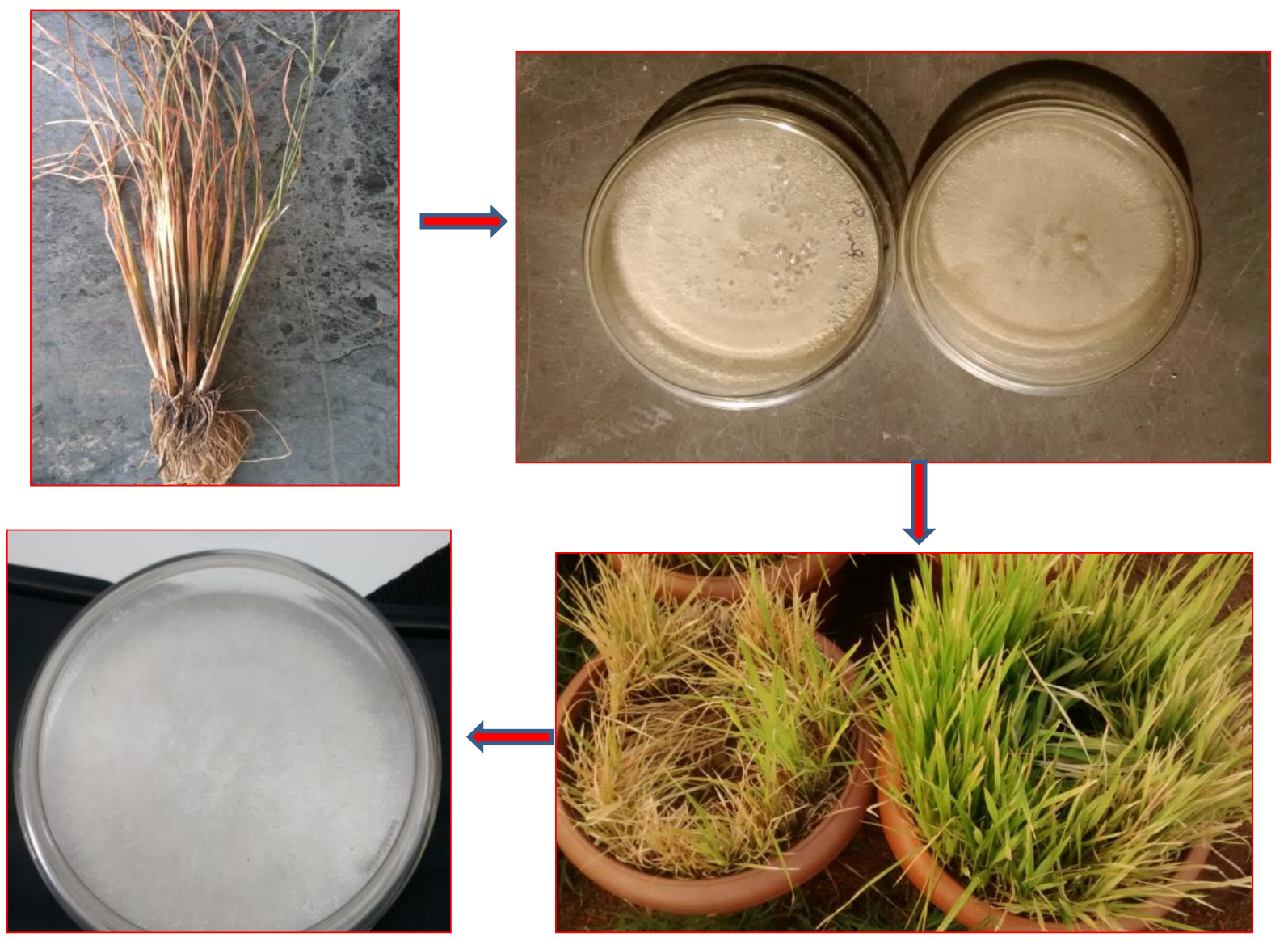
Although, information on its distribution and potential yield loss information is available from Northern and North eastern India, but same information from rice growing regions of Southern India is limited.

In the present study, eleven rice growing taluks of North-eastern Karnataka were surveyed for stem rot disease incidence. During the survey, we could identify the disease based on the symptomatology. First symptoms are generally observed after mid tillering stage. Initially symptoms appeared as small irregular lesions on the outer leaf sheath at water line. As the disease progress, lesions enlarge and spread to the inner leaf sheath and in later stage cause rotting of the associated culm and subsequent lodging (Fig. 1). Previously, Krause and Webster (1973) have reported that the tillering to internode elongation stage is the highly susceptible stage for this disease to cause maximum damage. During active tillering stage, the similar symptoms could be associated with the severe plant hopper damage followed by the infection of secondary saprophytic fungi and therefore, in our study association of the S. oryzae in symptomatic plants was identified through Koch's postulates (Fig. 2).

The average disease incidence in all eleven taluks surveyed was ranged from 12.35$29.55 \%$ (During Kharif 2014) and 3.71$14.33 \%$ (During Kharif 2015) (Tables 1 and 2). Earlier to this report, stem rot disease incidence and yield loss up to $30 \%$ was reported from Karnataka during Kharif 201213 (Pramesh and Guruprasad, 2014) and our present results from Kharif 2014 and 2015 will further support the wider distribution of this disease from Karnataka. The possible reason for its recent outbreak in north eastern Karnataka could be due to monocroping of paddy (with same susceptible cultivar such as BPT5204 for more than 30 years), extensive use of nitrogenous fertilizers and climatic change. Several previous studies have reported the increased incidence of stem rot due to high nitrogenous fertilizers (Keim and Webster, 1973). We could also observe the wider distribution of the disease across different paddy cultivation type (transplanted and direct seeded rice) and all the cultivated varieties of this region were affected (BPT5204, Kavery Sona, GNV-05-01, IR-64, Nellore Sona, etc, ). The information generated in the present investigation could be useful for prioritising the research to reduce the impact of stem rot disease and also to check its further development to cause disease epidemics.

\section{Acknowledgement}

This project was funded by the research and development grant from the department of Agriculture, Gov. of Karnataka (Project no. Ab.Ac. 5280). We are also thankful to Director of Research, UAS, Raichur for providing the necessary financial and work facilities.

\section{References}

AI-Heeti, M. B., and EI-Bahadli, A. H. 1982. Estimation of yield losses caused by Sclerotium oryzae Catt. on rice in Iraq. College Agric. Univ. Baghdad, Abu Gharib, Iraq: 113-114.

Cattaneo, A., 1876. Sullo Sclerotium oryzae nouvo parasite vegetable che ha devasto nel corrente anno molte risaje di lombardia e del Novarese. Rediconti R. Lombard., Milano. 2ser 9: 801-807.

Cother, E., and Nicol, H. 1999. Susceptibility of Australian rice cultivars to stem rot fungus Sclerotium oryzae. Australasian PI. Pathol. 28: 85- 91.

Gopika, K., Jagadeeshwar, R., Rao, V. K. and Vijayalakshmi, K., 2016. Salient resarch findings on rice stem rot disease (Sclerotium oryzae Catt.) and its 
management. International Journal of Plant, Animal and Environmental Sciences. 6(1).

Keim, R., and Webster, R. K. 1973. Nitrogen fertilization and severity of stem rot of rice. Phytopathology. 64: 178-183.

Krause, A. A. and Webster, R. K. 1973. Stem rot of rice in California. Phytopathology 63: 518-523.

Kumar, A., Singh, R. and Jalali, B. L., 2003. Management of stem rot of rice with resistance inducing chemicals and fungicides. Indian Phytopathology. 56(3):266-69.

Li, V.G., Kang, B.J., Feng, V.X., Huang, D.J" $\mathrm{Wu}, \mathrm{D} . \mathrm{B}$. and Li, T.F. (1984). A brief report on the studies of rice stem rot. Guangdong agriculture Science 5:35-37.

Ou, S. H., 1985. Rice Diseases, 2ndedn. Commonwealth Mycological Institute,
Surrey.

Pramesh, D., and Guruprasad, G. S., 2014. Stem rot disease of rice: an emerging disease threatening rice production in Karnataka. In National conference on "Emerging challenges and opportunities in biotic and abiotic stress management (ECOBASM-2014) during Dec 15-18 at DRR, Hyderabad.

Singh, N. I., and Devi, R. K., 1999. Departmental Disease Survey Report, College of Agriculture, CAU, Imphal. pp. 5.

Singh, R., Kumar, A. and Jalali, B. L., 2002. Variability, predisposing factors and management of stem rot caused by Sclerotium oryzae, An Overview. Annual review of plant pathology. 1: 275-289

\section{How to cite this article:}

Pramesh, D., Saddamhusen Alase, M. Kirana Kumara and Muniraju, K.M. 2017. Incidence of Stem Rot Disease in North-Eastern Region of Karnataka, India. Int.J.Curr.Microbiol.App.Sci. 6(10): 3007-3013. doi: https://doi.org/10.20546/ijcmas.2017.610.354 